\title{
TV/Series
}

$6 \mid 2014$

Écho et reprise dans les séries télévisées (III) : de la métafiction à la transmédialité

\section{Quatermass and the Pit: from British SF TV serial to Gothic Hammer film}

\section{Gaïd Girard}

\section{(2) OpenEdition \\ Journals}

Electronic version

URL: http://journals.openedition.org/tvseries/336

DOI: $10.4000 /$ tvseries.336

ISSN: 2266-0909

Publisher

GRIC - Groupe de recherche Identités et Cultures

Electronic reference

Gaïd Girard, «Quatermass and the Pit: from British SF TV serial to Gothic Hammer film », TV/Series

[Online], 6 | 2014, Online since 01 December 2014, connection on 20 April 2019. URL : http://

journals.openedition.org/tvseries/336 ; DOI : 10.4000/tvseries.336

\section{(c) (i) (9)}

TV/Series est mis à disposition selon les termes de la licence Creative Commons Attribution - Pas d'Utilisation Commerciale - Pas de Modification 4.0 International. 


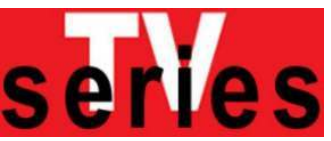

\section{Quatermass and the Pit: from British SF TV serial to Gothic Hammer film}

Gaïd GIRARD

This brief article aims at showing the shift of ideological and aesthetic perspective underlying the transposition of the 1950s Quatermass British TV serials to the later Hammer film version of the original BBC program. While the science fiction TV Quatermass reads as an obvious declaration of philosophical faith in the restoration of social normality and order in spite of alien threats from outer space, the Hammer films tend to enhance a more Gothic approach of a disaster film where uncertainties of all kinds eventually prevails. Post-WWII convictions and Cold War tensions either support or undermine the evolution of the plotline and its subterranean vision of the world as we pass from tv serials to films.

\section{From series to film: a few elements of context}

The Quatermass TV serials are a monument in the history of post-war British television. The three hugely popular serials - The Quatermass Experiment (1953), Quatermass II (1957), Quatermass and the Pit (1958-9) - were all written by Nigel Kneale and broadcast by the BBC between 1953 and 1959. They were transmitted live and did not resemble anything that had been done before; they gripped the entire nation - including the Queen ${ }^{1}$, combining for the first time science fiction and horror in sophisticated plots aimed at adults. In the early fifties, TV was basically "radio with pictures" according to Nigel Kneale. When the shooting of the first serial began, The BBC production team were unable to devise a credible man/monster; in order to signify astronaut Carroon's mutation, Kneale had to fabricate and operate huge fungus-like puppet hands which he filmed at close range. Working with director Rudolph Cartier, and using electronic music for the first time in this type of production, Kneale invented a truly "televisual" style².

The first two Quatermass stories were quickly adapted to the big screen by Hammer films (Val Guest, 1955-1957) whereas Quatermass and the Pit, a colour film directed by Roy Ward Baker, was released later in 1967. The original titles were retained in Britain, except for the first one, which was slightly altered to The Quatermass Xperiment, in order to cash in on the supposedly alluring power of the newly categorized Xrated films. But contrary to British television, Hammer

${ }^{1}$ Cf. "The Kneale tapes" in the BBC DVD bonus: when Nigel Kneale aired an adaptation of Orwell's 1984 after the first Quatermass serial, sections of the audience were shocked at the violence shown on TV. Questions were asked in Parliament, but it turned out that Buckingham Palace liked the programme and the outcry died off.

${ }^{2}$ Ibid.: see "The Kneale tapes" and "Conversation between Nigel Kneale and Rudy Cartier". 
films which included American financing from the start also targeted the American market3. Yet, Hammer productions always retained a specifically British flavour, not only because plots were set in Britain but also because the filming was done on location, in British country houses, landscapes, and small villages rather than in studios ${ }^{4}$. The Hammer style was distinctly different from that of Corman in the US or Bava in Italy, who also specialized in the horror genre.

The Quatermass films were huge hits on both sides of the Atlantic. In fact, it was the success of the first one, The Quatermass Experiment, that made Hammer shift its production to concentrate on the horror genre, so successful in the following years; films like The Curse of Frankenstein (1957), Dracula (1958), The Mummy (1959) developed a highly sensational and intense - some would say rather crude - visual style, foregrounding graphic violence and sexual titillation. This was also a response to the increased popularity of television, made more powerful by the arrival in 1955 of ATV, a new British commercial channel. Cinema audiences were starting to dwindle and Hammer films, which had always used stories adapted from the radio or from television, kept a close eye on what could draw spectators to see their films.

All these parameters should be kept in mind when working on the film adaptations of the Quatermass stories. Moreover, the proximity between TV and the cinema worked both ways: while Hammer adapted well-known TV serials to the big screen, the TV producer and director of the Quatermass serials, Rudolph Cartier, claimed that his aim was to "bring cinema effects to TV studios5", using for example inserted film sequences in his live studio recordings. Cartier, born in Austria, was a pupil of Max Reinhardt in Vienna. He originally worked as a scriptwriter and director in Berlin for the UFA studios, before fleeing nazism in 1935, following Billy Wilder to America; he finally settled in Great Britain. The lighting and some of the close range shots on the mutating astronaut's face in The Quatermass Experiment, the crowd scenes in Quatermass II, the mass killings in Quatermass and the Pit all bear obvious traces of Cartier's Austrian/German period, blended with American know-how. With the

3 The Quatermass films were retitled for the American market since the name Quatermass did not have the appeal it had for British audiences; respectively The Creeping Unknown (1955), Enemy from Space (1957), Five Millions years to Earth (1967).

4 Will Wright, "The Face of Quatermass: National Identity in British Science-Fiction", in Offscreen, 2008, Vol. 12, No. 10, http://offscreen.com/view/face_of_quatermass, last consulted on December $7^{\text {th }}, 2014$.

5 Cf. Nigel Kneale in the BBC DVD bonus: "Rudy put a lot on the small screen. He burst it open. That really did break the bounds of Mrs Smith drawing room". 
Quatermass stories, both the $\mathrm{BBC}$ and Hammer productions broke aesthetic and visual ground in popular media ${ }^{6}$.

\section{Recycling a British background}

Quatermass and the Pit, the third and most acclaimed production of the Quatermass serials is the only one for which Nigel Kneale wrote the scripts both of the TV serial and the film. In an interview with Paul Wells, Kneale explains that when he started working on science-fiction stories, he wanted to do something different from the usual simplistic American science fiction movies, and that he aimed at "something British but not flag-waving, something with real human interest and some good humour ${ }^{7}$." He also declared that he preferred the TV serial to the filmic version of his story, which "suffered from shrinkage" and never allowed room for comic relief, to ease off the melodrama. "Film story telling is cruder," he bluntly concludes ${ }^{8}$. Obviously, six 35-minute-long TV episodes can say more than a 93-minute-long film. But besides the issue of time and length, one of the distinctive features of the TV serials which is not to be found in the film lies in the way this obviously highly fictional story of ancient beings coming from outer space and having caused the human race to mutate is deeply anchored in British social reality.

An outline of the story has to be given here before going any further. As in all the other Quatermass stories, the main character Bernard Quatermass, the head of the British Experimental Rocket Group, has to wrestle with an alien threat from outer space. In Quatermass and the Pit, the danger seems to have been lying in wait for over five million years in the form of a strange capsule unearthed by construction workers in the heart of London. Primitive humanoid skulls lying about and dead horned insects found in the capsule point

${ }^{6}$ Cf. BBC Screenonline: "Cartier exploded the myth that television was by its nature smallscale, having to aspire to the 'intimate'. He excelled in staging wide-ranging stories, large vistas, and crowd scenes in the studio, spectacles hitherto believed inimical to television. To do this he often inserted extensive pre-filmed sequences into his live productions. While other directors used such inserts as little more than filler material or for scene setting, in Cartier's hands they brought the story to life, allowing it to expand beyond the cramped studio. (...) This highly visual aspect of his work has led some to call Cartier's style 'cinematic.' However, his large-scale images were not big pictures as for a big screen, but images that challenged the confines of the domestic screen. As such, his work is essentially 'televisual.' http://www.screenonline.org.uk/people/id/1181098/, last consulted on December $7^{\text {th }}, 2014$.

7 "I wanted to write some strong characters, but did not want them to be like those horrible people in those awful American science fiction films, chewing gum and stating the obvious. Not that I wanted to do something terribly British, but I really didn't like all the flag waving you got in those films. I tried to get real human interest in the stories, and some good humour.", in Paul Wells, "Apocalypse then! The ultimate monstrosity and strange things on the coast... An interview with Nigel Kneale", in I.Q. Hunter (ed.), British Science Fiction Cinema, London and New York, Routledge, 1999, p. 50.

${ }^{8}$ Ibid., p. 54. 
to the mind-boggling hypothesis offered by Quatermass and the paleontologist, Roney: five millions years ago, Martians decided to colonize the earth by proxy since life on their planet was doomed. They imported terrestrial apes and through something akin to selected breeding and atomic surgery, they implanted in them higher intelligence and new faculties, together with memories of life on Mars, before bringing them back to earth.

The capsule found in the excavation must have been an accident in which all creatures died, Martian insects and Earth apes alike. Other spaceships must have fulfilled their mission to allow the implantation of Martian genes in humankind, thus enabling its progression, in the manner of the black monolith in Kubrick's 20019. As TV Quatermass claims: "We are the Martians now"; indeed, most of them are just that - mutated human beings complete with dormant archaic memories of elimination and the mass slaughter of deviant individuals. As the energy of the capsule is liberated, some humans standing near it begin to experience headaches and visions of insect mass killings which send them reeling and screaming away; those images look like ancient cave drawings, descriptions of ghost sightings and uncanny phenomena in the area dating back to the $17^{\text {th }}$ century, thus bridging alien insect-like creatures with the dawn of humanity.

In a climatic final scene, the capsule fed by a TV power line glows white and sends the entire London population on a rampage; any human being immune to the mutation that took place five million years before is ruthlessly killed. Roney, one of the few immune people, who succeeds in escaping the murderous crowd hurls iron into the mass of energy emanating from the capsule and ultimately destroys it, sacrificing his life in the process. Londoners, and eventually the human race, are saved.

As was said, Nigel Kneale preferred the time and space given by the TV serial format, which gives full scope to his view that a kind of balance between melodrama and humour should be kept ${ }^{10}$. Indeed, the TV episodes are interspersed with funny and typically British scenes linked with beer and whisky in the pub, tea (stretching as far as reading tea leaves) in sitting room, and leisure (the audience is treated to a narrative of a fantastic trout fishing party). They also draw on British reality and a tradition of realistic British documentary on TV: the first episode mentions race riots, recalling for contemporary audiences the Notting Hill race riots of 1958 , while a black construction worker is shown on screen together with other middle-aged workers. This does not appear in the film.

Yet, the film retains from the TV serial several socially and politically related issues: an obvious reference to images of the London

92001 A Space Odyssey was released in 1968.

${ }^{10} \mathrm{Cf}$. Paul Wells, op. cit., p. 54. 
Blitz, only a few years back and still vivid in the memory of British people; a pointed criticism of narrow minded and dangerous army bureaucrats ${ }^{11}$; a sexist attitude towards Roney's assistant Barbara Judd; last but not least, a surprisingly lucid awareness of media matters, and the role of television in particular. Indeed, in both the TV serial and the film, a TV news bulletin broadcast live from the pit is interrupted before the very eyes of pub customers who complain about missing their next program. A cut back to the pit shows a scene of pandemonium where camera and reporters are trampled over by a panic-stricken crowd. Disaster makes reporting impossible, and television is outdone by the magnitude of the catastrophe. Reality becomes too excessive for static TV to represent it adequately. Yet, the end of the serial reinstates the $\mathrm{BBC}$ as the privileged medium to analyse and make sense of the world and human nature. Contrarily, the film offers a very different conclusion by showing a last image of utter disaster in deserted London.

\section{Two endings / two widely different cultural agendas}

In the serial ending, the destruction of the capsule is represented with much economy and virtually no special effects. A white screen with appropriate soundtrack signifies the destruction of the pulsating source of energy and the disappearance of Roney. When the smoke clears, only white rubble is left scattered at the bottom of the excavation. In the epilogue, Quatermass, filmed by the BBC, surrounded by all the representatives of society, including a priest, delivers the moral of the story and transforms Roney into a hero who singlehandedly defeated the not-so-alien force and sacrificed himself for humanity. The menace of our own impulse for destruction is channelled back into language in the form of a lucid, rational conclusion, appealing to human reason, with a whiff of the allegorical ${ }^{12}$. Thus the BBC recovers its function as the recording instrument of social normality and order; Quatermass' concluding speech partakes more of Shakespeare's epilogues than of cinematographic last shots. This ending can be seen as a hymn to the role of the BBC, with the last shot pointedly showing the studio sign "SOUND ON/VISION ON".

Drawing on much more extensive technical means, the ending of the Hammer film is obviously more spectacular, but also deeply different in spirit and aesthetics. The shot of the energy-laden horned

${ }^{11}$ Kubrick's Dr Strangelove was released in 1964.

${ }_{12}$ Here is the end of Quatermass' speech: "We are armed with knowledge. We also have knowledge of ourselves and of the ancient destructive urges in us that grow more deadly as our populations increase and approach the size and complexity of those of ancient Mars. Every war, crisis, witch-hunt, race riot, purge, is a reminder and a warning. We are the Martians. If we cannot control the inheritance within us, this will be their second dead planet." 
devil rising hugely against the London sky cannot help triggering memories of white atomic clouds and post-world-war-II angst. It is all the more efficient as its appearance has been built throughout the film on the dialectics between underground forces of the past and cosmic threats of elimination, in keeping with Gothic vertical aesthetics. Contrary to the TV serial where the excavation was carried out at ground level and the artefact was found lying horizontally, the film locates the capsule deep in the London underground, at Hobb's Lane tube station. This shift creates a totally different sense of space, including numerous high- and low-angle shots taken in the pit and many darkened shots typical of Gothic aesthetics. The depth of the drilling allows very slimy earth to be shovelled out in order to unearth the space ship. The sheer primitive physicality of the location is made much more impressive and paves the way for the horrifying bodies of the insects, which putrefy under our gaze the minute they are exposed to open air, in true Lovecraftian manner. Baker makes extensive use of colour here: greenish fluid oozes out of the Martians' bodies, turning everybody's stomach inside out (see plate 1). The TV insects looked much more civilized (see plate 2).

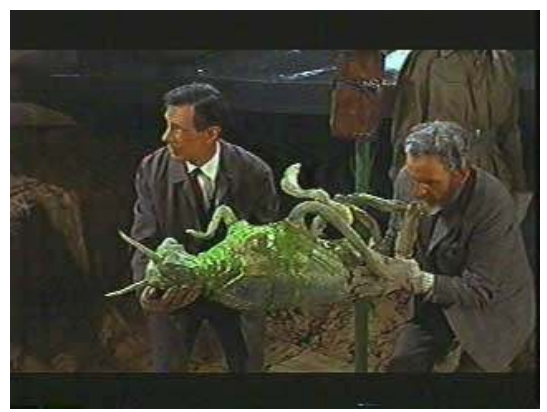

Plate 1: Green gore in the film version

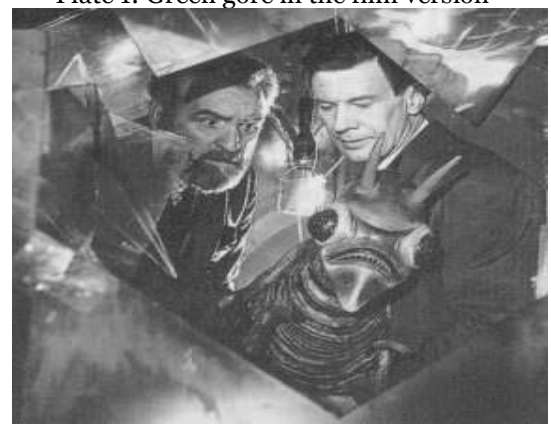

Plate 2: $\mathrm{BBC}$ version of the Martians 


\section{Threatened British masculinity}

From the film's womb-like slimy pit, unleashed telluric forces are redirected upwards into a highly phallic and cinematic idol-like shape shimmering in the sky (see plate 3). This effigy which holds nearly the entire population in a zombie-like murderous trance (Romero's living dead are only a year away) is ultimately attacked by another thrusting tower of strength, a metallic crane ridden by heroic Roney. An epic confrontation takes place between two male powers fighting for the control of London/the earth and the Human Mind. This highly sexualized scene - a hallmark of the Hammer manner - points to a hysterical response to threatened British masculinity.

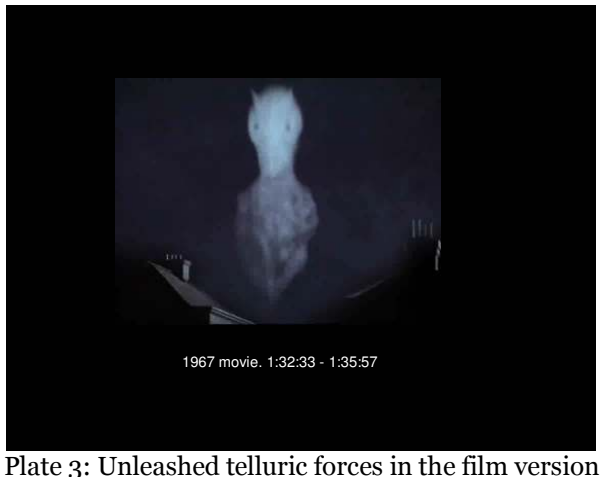

Indeed, more obviously in the film than in the TV serial, Barbara Judd, Roney's assistant is an unstable construction: her brain is more susceptible than her male counterparts' to the influence of the forces emanating from the capsule, and she is the medium through which Quatermass understands the pattern of ritual slaughter which has been planted in most human brains for five million years ${ }^{13}$. She is also an efficient and smart assistant, and the sexual focus of the whole film, reminiscent of James Bond girls. But, in the last scene, she errs zombie-like in the street before Quatermass socks her, knocks her out and slings her over his shoulder, in cliché barbaric fashion - a rather extreme gesture which nevertheless seemed necessary for the rounding up of the narrative and the final victory of civilization.

Physical mistreatment of women is frequent in the Hammer horror tradition and is also a staple of the Gothic genre. Hammer's sensational treatment of the Quatermass and the Pit story develops in

${ }^{13}$ Roney has devised a machine which records the brain waves of individuals and projects them on a screen for the others to see. 
a rather frenetic style what was already graphically present in the TV serial, i.e. issues of uncertain masculinity. But whereas the serial reinstates male control and order, turning a science fiction drama into a post-war meditation on human nature, the film, shot nearly ten years later in 1967, leaves gender issues stridently open. Gothic horror has always been a means of addressing unresolved social and political contradictions and Hammer's Quatermass and the Pit is no exception.

Not only does it graphically echo nuclear holocaust through the white hot silhouette towering over London but it also ends on a dire vision of defeated British manhood, represented by a limp, slumping Quatermass, and pointing to the insignificance of a nation squeezed between two cold war giants, especially after the Suez crisis (1956). The credits roll on two broken characters, a man and a woman isolated in depressed post-war London where only the siren of a firemen's engine can be heard in the distance. The ultimately philosophical BBC serial has given birth to a gothic disaster film; the issue of post-holocaust humanity and the strictly gendered fabric of society lie at the core of both narratives by pessimist Nigel Kneale. Paradoxically, Barker's wasteland leaves room for a totally new London to emerge, such as in Antonioni's Blow Up (1966) or Nicholas Roeg's Performance (1970) where new media and altogether another Britain will be given pride of place.

\section{Bibliography}

BRUNDSON Charlotte, “'A fine and private place': the cinematic spaces of the London Underground", Screen 47(1), 2006, p. 1-17.

HunTer I.Q. (ed.), British Science Fiction Cinema, London and New York, Routledge, 1999.

Hutchings Peter, "We are the Martians now", I.Q. Hunter, British Science Fiction Cinema, London, Routledge, 1999, p. 33-47.

Hutchings Peter, Hammer and Beyond: the British Horror Film, Manchester, Manchester University Press, 1993.

JAMESON Fredric, Archaeologies of the Future, London, New York (2005), Verso, 2007.

Johnson William, "Mars Attacks”, Film Comment, March-April 1997, p. 64-67.

Suvin Darko, "On the Poetics of the Science Fiction Genre", College English, Vol. 34, No. 3, December 1972. 
WELLS Paul, "Apocalypse then! The ultimate monstrosity and strange things on the coast... An interview with Nigel Kneale", I.Q. Hunter (ed.), British Science Fiction Cinema, London and New York, Routledge, 1999, p. 48-56.

WRIGHT Will, "The Face of Quatermass: National Identity in British Science-Fiction”, Offscreen, 2008, Vol. 12, No.10,

http://www.screenonline.org.uk/people/id/1181098/, last consulted on December $7^{\text {th }}, 2014$.

\section{The Author}

Gaïd Girard is a full professor at the UBO (University of Western Britanny). Her areas of interest include the Gothic and the Fantastic, especially in Irish Literature and the Visual Arts (she published a book on Irish author Sheridan Le Fanu and edited another one on the Uncanny in Irish Literature). She has recently co-edited an on-line journal issue about Ireland and photography. (Lisa Vol. 12, No. 3 | 2014, Freeze-Frame: Photography, Icons and Literature in Ireland / Arrêt sur Image : Photographie, icônes et littérature en Irlande http://lisa.revues.org/5876). She has also written extensively on cinema (Kubrick, Roeg, Epstein, Marker and SF in general). She is currently working on representations of the Posthuman within the research group she heads in Brest, Heritages and Constructions in Texts and Images (http://www.univbrest.fr/hcti). 